\title{
A new approach for identification of the genus Paralia (Bacillariophyta) in Korea based on morphology and morphometric analyses
}

\author{
Suk Min Yun ${ }^{1}$, Sang Deuk Lee ${ }^{2}$, Joon Sang Park ${ }^{1}$ and Jin Hwan Lee ${ }^{1, *}$ \\ ${ }^{1}$ Department of Life Science, Sangmyung University, Seoul 03016, Korea \\ ${ }^{2}$ Freshwater Bioresources Research Division, Nakdonggang National Institute of Biological Resources, Sangju 37242, Korea
}

Paralia species have been frequently reported as P. sulcata in Korea, despite the species diversity within the genus. To understand the species diversity of Paralia in Korea, we collected phytoplankton samples at 79 sites from April 2006 to April 2015. Five Paralia species, P. fenestrata, P. guyana, P. marina, P. cf. obscura, and P. sulcata, were observed during this study, and we described their fine structure in terms of quantitative and qualitative morphological characteristics. To provide additional criteria to identify Paralia species more clearly, we morphometrically analysed four quantitative characteristics on valve diameter: pervalvar axis / diameter, internal linking spines / diameter, marginal linking spines / diameter, and fenestrae/diameter using non-metric multidimensional scaling (MDS). MDS analysis distinguished four Paralia species: P. guyana, P. marina, $P$. cf. obscura, and P. sulcata, with the exception of $P$. fenestrata. This new approach in using morphometric analysis is useful for the accurate identification of Paralia species.

Key Words: diatom; morphometric analysis; non-metric multidimensional scaling (MDS); Paralia; taxonomy

\section{INTRODUCTION}

The centric diatom genus Paralia is frequently found as a tychoplankton in vertically mixed coastal waters (e.g., Hajós 1973, Řeháková 1975, Crawford 1979, Loseva 1988, Crawford et al. 1990, McQuoid and Nordberg 2003). This genus has been used as a bioindicator in ecological studies. Currently, 18 recognized species exist (Guiry and Guiry 2016). Despite its species diversity, most ecological studies have documented each member of the genus as Paralia sulcata (e.g., McQuoid and Nordberg 2003). Recently, MacGillivary and Kaczmarska (2015) mentioned that there is a cryptic diversity of Paralia species in the world. Additionally, the morphologically complex structure of Paralia increases the difficulty in species recognition.
Paralia species form solid chain colonies by cell butting. Its valves are robust, circular, slightly convex, and display double heterovalvy, namely, possessing intercalary and separation valves (Crawford 1979). The sibling valves are within the chains, and linked by well-developed interlocking ridges, grooves, and marginal spines. The separation valves are located at the end of each chain, with reduced ridges and no marginal spines. These features impede proper identification of the Paralia species.

Paralia was first established with the species Paralia marina (Smith) Heiberg (Heiberg 1863). However, this species had already been reported as Gaillonella sulcata by Ehrenberg (1838), and as Orthoseira marina by Smith (1856). Cleve (1873) reported many varieties and forms of terms of the Creative Commons Attribution Non-Commercial License (http://creativecommons.org/licenses/by-nc/3.0/) which permits unrestricted non-commercial use, distribution, and reproduction in any medium, provided the original work is properly cited.
Received January 11, 2016, Accepted March 7, 2016

*Corresponding Author

E-mail: jhlee@smu.ac.kr

Tel: +82-2-2287-5152, Fax: +82-2-2287-0098 
P. sulcata (Ehrenberg) Cleve. These species, such as Paralia var. crenulata Schmidt and var. siberica Schmidt, have been described (Schmidt 1874-1959). Crawford (1979) re-described Paralia and was the first to rearrange the nomenclature. The fossil $P$. siberica (Schmidt) Crawford and Sims was formerly a variation of species $P$. sulcata (Grunow 1884). However, it was elevated to species level by Crawford et al. (1990), and was distinguished by the mantles of the valves and the shape of the marginal linking spines. Stabell (1996) found a new fossil species, $P$. thybergii, from upper Oligocene sediments in the northern North Sea. Sims and Crawford (2002) observed two new fossil species: P. fausta (Schmidt) Sims and Crawford and $P$. hendeyi Sims and Crawford. New extant species have been suggested by virtue of their morphological differences (e.g., valve shape, face, spines of the valve, and pattern of linking spines): P. elliptica Garcia, $P$. longispina Konno and Jordan, P. allisonii MacGillivary, $P$. crawfordii MacGillivary, P. ehrmanii MacGillivary, P. capitata Sawai and Nagumo, and P. fenestrata Sawai and Nagumo. Recently, MacGillivary and Kaczmarska (2013) reported P. obscura MacGillivary and other species (P. sulcata, $P$. fenestrata, and $P$. fausta) in sediment samples from Oran, Algeria, and later dated them to the Miocene from the Ehrenberg collection. MacGillivary and Kaczmarska (2015) studied P. marina and first reported P. guyana MacGillivary (with four genodemes: 'smooth,' 'caisn,' 'capebreton,' and 'servidei' valves) using molecular, morphological, and morphometric analysis.

Morphometric analysis is very useful for characterpoor species (Pappas et al. 2001). Shape analysis has proven to be an especially useful method, because shape is commonly the first distinguishing characteristic of many species, such as diatoms (Pappas et al. 2001). Many previous studies of diatoms have involved morphometric analysis of their fine structure (e.g., valve outline, spine, striae, and rimoportulae). Some studies have measured the simple shape, such as valve outlines, which, although they are not reciprocal, can nevertheless be highly effective in separating semi-cryptic or cryptic species, e.g., of the genus Diploneis (Droop 1994, Droop et al. 2000). Additionally, a more efficient morphometric method is used to correct classification, involving quantitative data on cell shape, such as Legendre polynomials (Stoermer and Ladewski 1982, Stoermer et al. 1986, Theriot and Ladewski 1986, Steinman and Ladewski 1987, Goldman et al. 1990, Rhode et al. 2001, Pappas and Stoermer 2003) and Fourier coefficients (Mou and Stoermer 1992, Pappas et al. 2001). These studies suggest that valve outlines or shape features, combined with statistical analysis meth- ods (e.g., principal components analysis), can be useful for morphological investigation in diatoms. Thus, these survey data can help solve taxonomic problems at the species level.

The aim of this study was three-fold. First, the present study provides a detailed survey of the genus Paralia species from Korean coastal waters. This survey includes morphological details revealed by light microscopy (LM) and scanning electron microscopy (SEM). Second, we determine which types of characteristics for Paralia identification are important. Finally, our intention was to develop a method of identification of Paralia species based on morphological features and biometric data. Using the morphometric data obtained from the Paralia species, we propose an easier classification method.

\section{MATERIALS AND METHODS}

To compare specimens that previous studies identified as Paralia with living specimens of Paralia from Korean coastal waters, Paralia species were collected from April 2006 to April 2015 at 79 sites along the Korean coast (Supplementary Table S1). Samples were collected at a water depth of approximately $10 \mathrm{~m}$, using a $20-\mu \mathrm{m}$ mesh plankton net, by oblique or vertical towing from the Korea coastal water. Net samples were immediately fixed with neutralized formalin (final concentration of $4 \%$ ), glutaraldehyde (final concentration of 2\%), and Lugol's solution.

Specimens were observed under LM and SEM. The organic matters in water samples were removed following the protocol developed by Hasle and Fryxell (1970) and Simonsen (1974), with some modifications. The permanent slides were examined under LM (Axioskop 40; Carl Zeiss, Oberkochen, Germany). LM micrographs were taken using an Axiocam MRc5 digital camera (Carl Zeiss). Some cleaned materials were examined using SEM (JSM5600LV; Jeol, Tokyo, Japan). The dimensions of frustules in the LM and SEM images were measured using Image J 1.32 software (Schneider et al. 2012).

We identified initial definitions to guide the first morphological features and biometric data-gathering phase, then reviewed and confirmed them on the basis of the available data. The characteristics of Paralia species, 'Internal linking spines in $10 \mu \mathrm{m}$,' 'Marginal linking spines in $10 \mu \mathrm{m}$,' and 'Fenestrae in $10 \mu \mathrm{m}$,' were relatively stable. However, other characteristics were more variable (e.g., the shape of the tops of the internal and marginal linking spines and the shape of fenestrae). Thus, these characteristics were combined with 'diameter.' Each characteristic 
is defined as follows:

1) The ratio of the pervalvar axis to the diameter. Defined as the change in the length of the pervalvar axis due to a change in diameter.

2) The ratio of internal linking spines to diameter. Defined as the change in the internal linking spines within $10 \mu \mathrm{m}$ due to a change in diameter.

3) The ratio of marginal linking spines to diameter. Defined as the change in the marginal linking spines within $10 \mu \mathrm{m}$ due to a change in diameter.

4) The ratio of fenestrae to diameter. Defined as the change in the fenestrae within $10 \mu \mathrm{m}$ due to a change in diameter.

Terminology used follows the general proposals of Crawford (1979), Round et al. (1990), and MacGillivary and Kaczmarska (2015).

Data for morphological features were analysed using the statistical software Primer v6 (Primer-E Ltd., Lutton, UK) (Clarke 1993, Clarke and Ainsworth 1993, Clarke and Warwick 2001). Non-metric multidimensional scaling (MDS) was applied to complement the characteristics of Paralia species relationships that were found, utilizing the clustering procedure, and to explain the relationships in a two-dimensional space. The procedure for MDS was calculated with 25 restarts to arrive at a minimum stress value of 0.01 , according to the procedures developed by Field et al. (1982) and Clarke (1993). For the morphometric measurements in digital images, ImageJ software (National Institutes of Health, Bethesda, MD, USA) was used.

\section{RESULTS}

Five species belonging to the genus Paralia (approximately 1,500 cells altogether) were identified from Korean coastal waters. Morphological features of the five species found in this study were compared with previously published literature (Table 1). We investigated the ultrastructural characteristics of the five species (Table 1, Fig. 1). In this study, we focused on the internal and marginal linking spines, fenestrae, cingulum, striae, areolae, and rimoportulae (Figs 2-7). These taxa were mostly morphologically similar species (Figs 2-7), and were described based on morphometric criteria for identification.

\section{Paralia fenestrata Sawai \& Nagumo (Table 1, Fig. 2)}

Description of specimen morphology based on LM. Straight chains were formed of interlocking cells (Fig. 2A). Cell chains were mostly $<20$ cells. Frustules were cylindrical and strongly silicified, 8.6-50.8 $\mu \mathrm{m}$ in diameter and 5.1-18.6 $\mu \mathrm{m}$ in pervalvar axis. Sibling valve chains linked with well-developed interlocking (Fig. 2A). Valves almost circular (Fig. 2C \& E). Separation valves had lined up along the central region of internal spines (Fig. 2C, thin arrow) and fenestrae (Fig. 2C, thick arrow). Internal valves had lined up along the central region of internal spines (Fig. 2E, thin arrow) and fenestrae (Fig. 2E, thick arrow).

Description of specimen morphology based on SEM. Straight chains were formed of interlocking cells (Fig. 2B). Two types of valves were observed, separation (Fig. 2D) and intercalary valves (Fig. 2 F), each type with two very similar forms, relief and intaglio. Spatulate marginal linking spines (Fig. 2G, thick arrow), 4.3-10.0 in $10 \mu \mathrm{m}$, occurred only along the face margin of intercalary valves and fit into notches (Fig. $2 \mathrm{H}$ ) between the marginal region. Internal linking spines of varied size, 6.1-17.0 in 10 $\mu \mathrm{m}$, tapered in height towards the smooth valve central area (Fig. 2F \& G, thin arrow). The marginal and internal linking spines of sibling valves interlocked to united cells in colonies (Fig. 2B \& H, thick and thin arrow). Separation valves were without marginal linking spines (Fig. 2B \& D). Separation valves had smooth and convex valves, lined up along the central region of internal spines (Fig. 2B \& D, thin arrow). Commonly, double rings of larger and smaller pores were irregularly present at the valve face margin of marginal and intercalary valves (Fig. 2D \& F, thick arrow). The most exterior pores on the valve face contained larger pores than the interior pores (Fig. 2D \& F, thick arrow). The arrangement of the interior ring of pores was variable (Fig. 2D \& F). In some valves, pores were irregularly spaced (Fig. 2D). The valve faces were slightly convex, flat, and with a cylindrical girdle outline of the frustule (e.g., Fig. 2A \& B). All valves were perforated by small circular areolae, in parallel crossing rows forming a decussate pattern (Fig. 2G, dashed square), 3.4-4.5 in $1 \mu \mathrm{m}$ in internal valve view. The fenestrae were obvious at the base of the valve face and the mantle; $3.4-10.0$ in $10 \mu \mathrm{m}$ in girdle view. Above each fenestra was a large circular pore in the valve face (Fig. 2G \& H), which corresponded to the presence of a marginal linking spine in intercalary valves. Thus, fenestrae and marginal linking spines nearly occurred at a ratio of $1: 1$ (Fig. $2 \mathrm{G} \& \mathrm{H}$ ). Cingula were composed of a number of regularly spaced copulae. Cingula were plain except for regularly spaced slits, 28.6-49.1 in $10 \mu \mathrm{m}$ (Fig. 


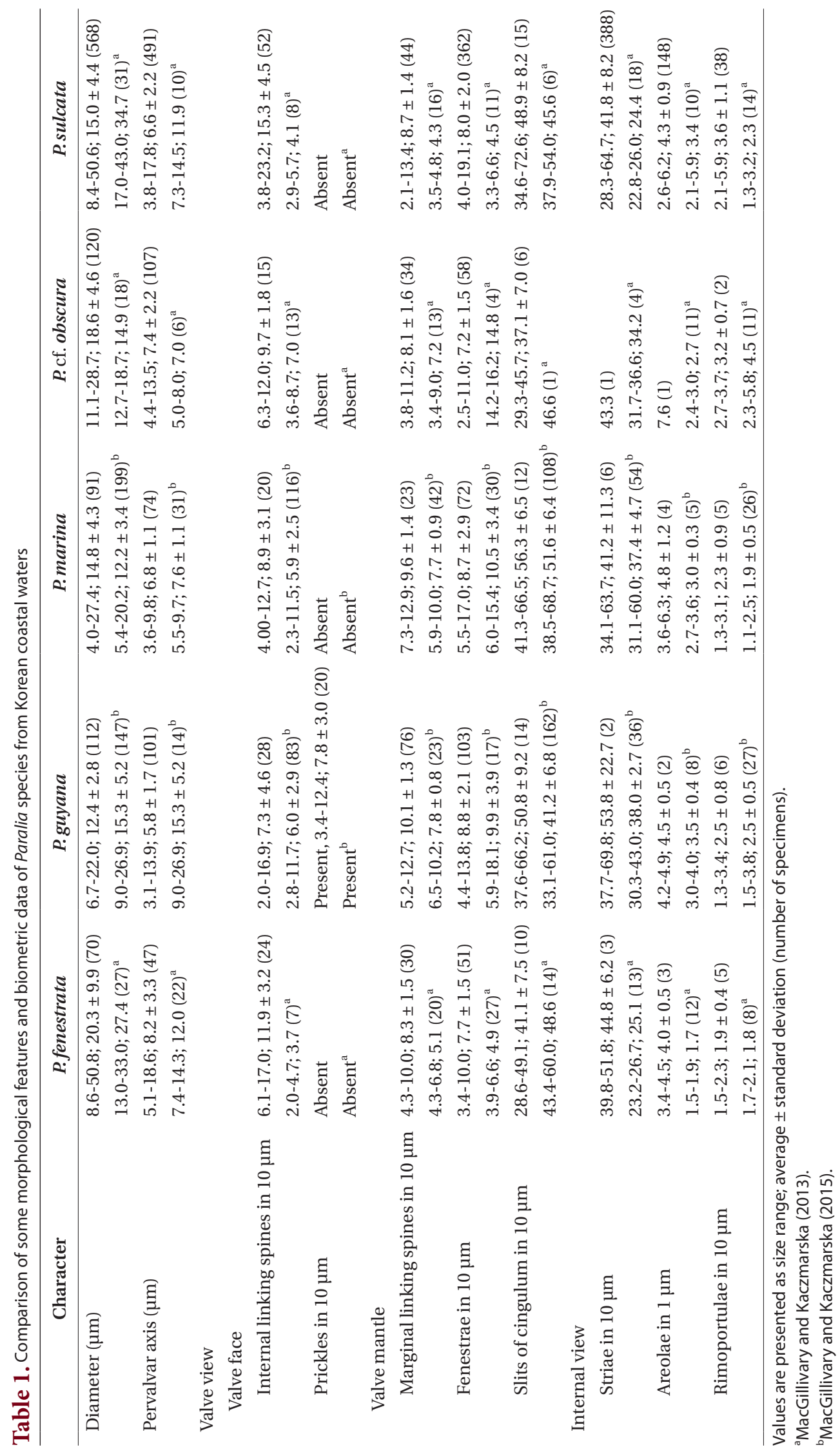



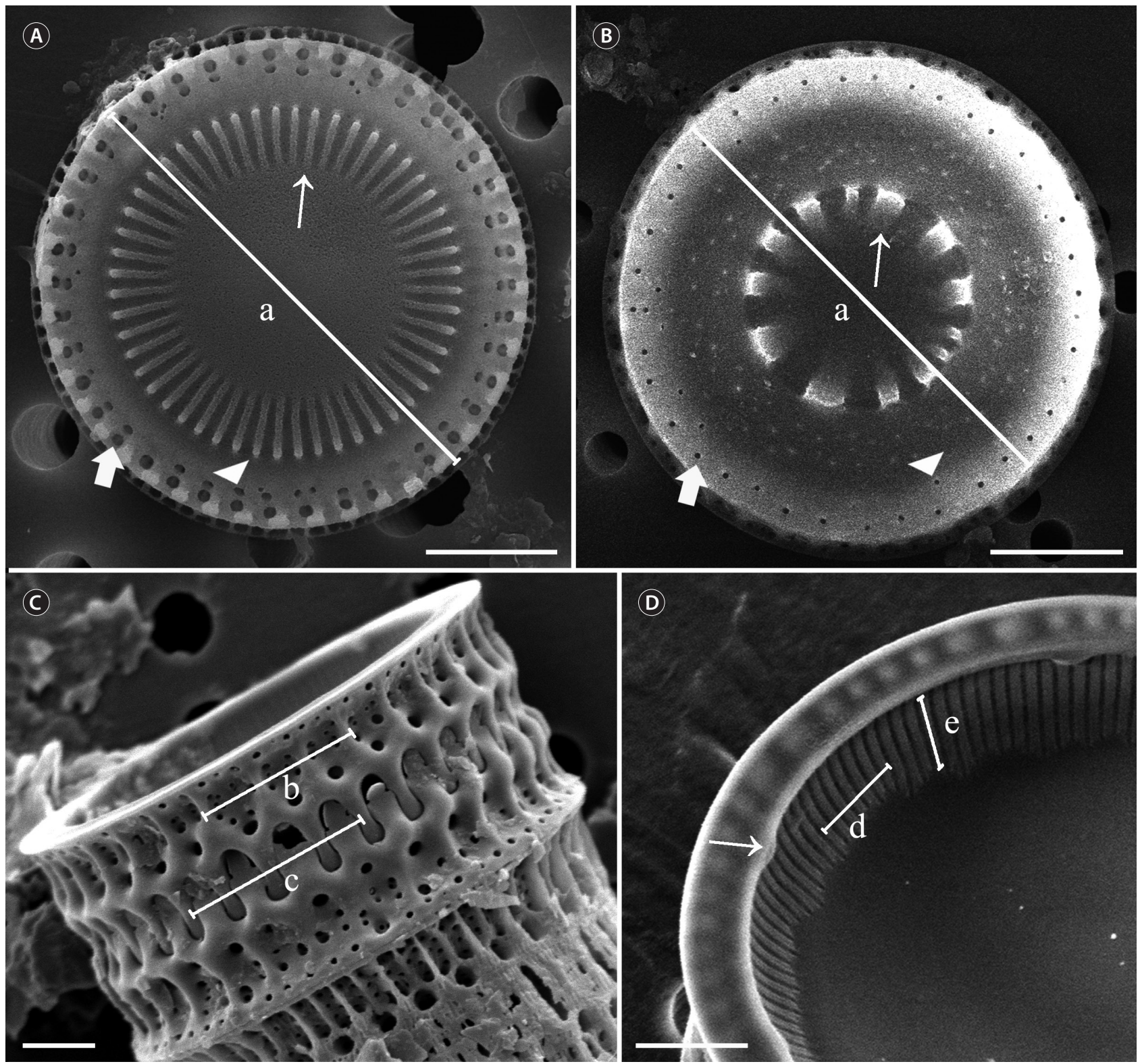

Fig. 1. How the Paralia valve characters were measured and taken using scanning electron microscopy. (A) Intercalary valve face view. Diameter (a), internal linking spines (thin arrow), outer marginal pores (thick arrow), inner marginal pores (arrowhead). (B) Separation valve face view. Diameter (a), internal linking spines (thin arrow), outer marginal pores (thick arrow), inner marginal pores (arrowhead). (C) Number of fenestrae (b), number of marginal linking spines (c). (D) Internal valve view. Number of striae (d), number of internal stria pores (e), rimoportula (thin arrow). Scale bars represent: A, $5 \mu \mathrm{m}$; B-D, $2 \mu \mathrm{m}$. 

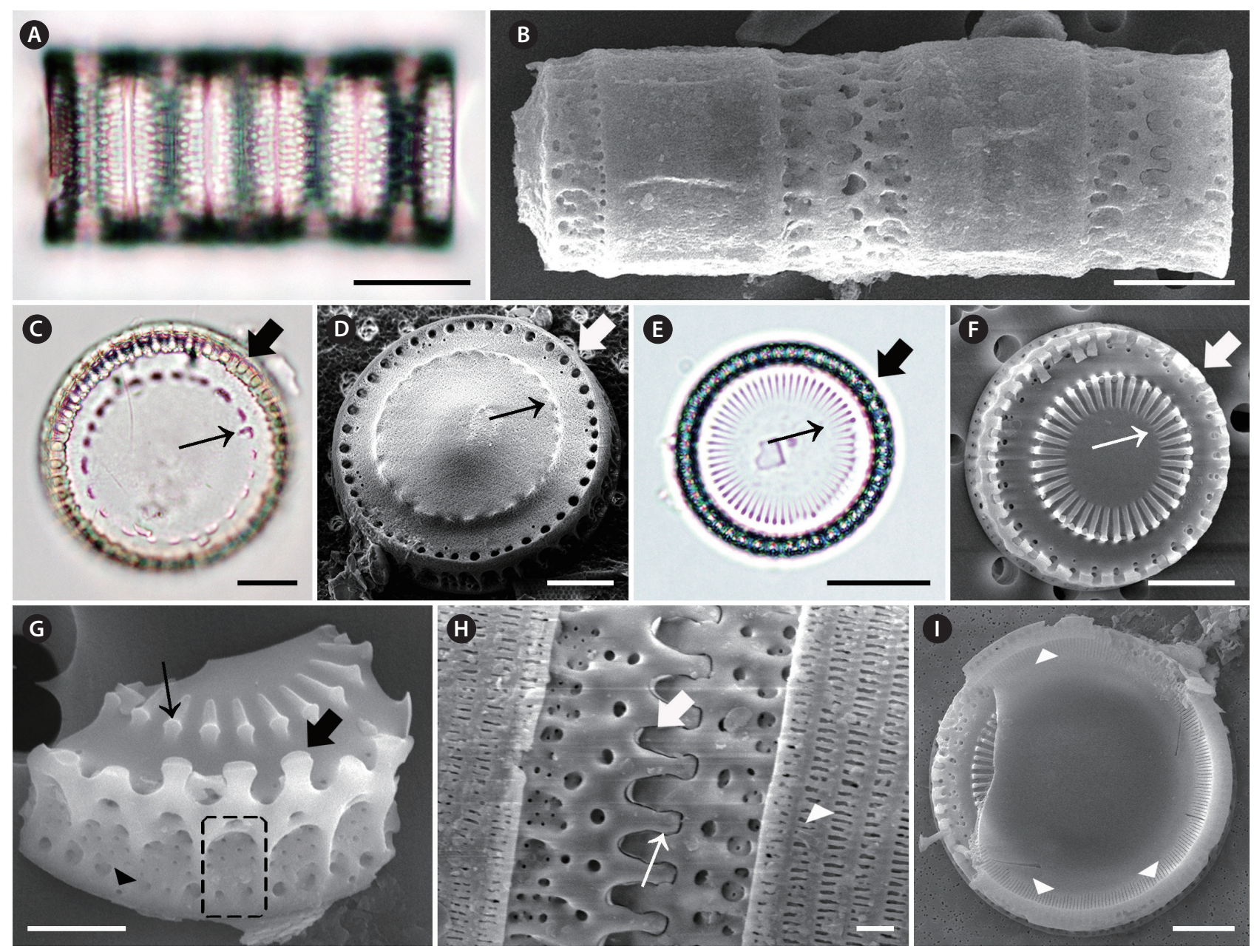

Fig. 2. Micrographs of Paralia fenestrata taken using light microscopy (A, C \& E) and scanning electron microscopy (B, D \& F-I). (A \& B) Girdle view of four-celled chain. Upper (A) focus girdle view of the specimen. (C) Valve view of separation valve. Internal linking spines (thin arrow), marginal pore (thick arrow). (D) Valve view of separation valve. Internal linking spines (thin arrow), marginal pore (thick arrow). (E) Valve view of intercalary valve. Internal linking spines (thin arrow), marginal pore (thick arrow). (F) Valve view of intercalary valve with interlocking radiating processes. Internal linking spines (thin arrow), marginal pore (thick arrow). (G) Valve view of intercalary valve. Internal linking spines (thin arrow), marginal linking spines (thick arrow). Visible fenestra (dashed square), external pore of the rimoportula (arrowhead). (H) Girdle view of two cells. Each cell has marginal linking spines and copulae. Marginal linking spines (thin arrow) in relief valve, marginal linking spines (thick arrow) in intaglio valve, slits in copulae (arrowhead). (I) Internal valve view. Rimoportula (arrowheads). Scale bars represent: A \& C-E, $10 \mu \mathrm{m} ; \mathrm{B}, \mathrm{F} \& \mathrm{I}, 5 \mu \mathrm{m} ; \mathrm{G}, 2 \mu \mathrm{m} ; \mathrm{H}, 1 \mu \mathrm{m}$.

$2 \mathrm{H}$, arrowhead). The mantle rim was flat and smooth in internal valve view (Fig. 2I). Small, simple slit rimoportulae were located near the mantle edge and were irregularly spaced; 1.5-2.3 in $10 \mu \mathrm{m}$ (Fig. 2I, arrowheads). The external openings of the rimoportulae were clear (Fig. 2G, arrowhead). Striae ran below the mantle edge in internal view. Striae were perpendicular to the mantle edge and were parallel to each other when they were present (39.851.8 in $10 \mu \mathrm{m})$.

Remark. Sawai et al. (2005) recently recorded $P$. fenestrata, and Garcia et al. (2012) recorded and described P. fenestrata in the waters of southern Brazil and described. However, separation and intercalary valves of
P. fenestrata from Garcia et al. (2012) show a single row of pores on the valve face, but in this and other studies (e.g., Sawai et al. 2005, MacGillivary and Kaczmarska 2013) two rings were described. In addition, according to MacGillivary and Kaczmarska (2013), this species was always observed forming short, straight, filamentous colonies of 4-10 cylindrical and strongly silicified cells (MacGillivary and Kaczmarska 2013). During this study, P. fenestrata was no different from previous research. However, the diameter range of $P$. fenestrata that we observed from the Korean coastal waters was wider than that of the previously studied $P$. fenestrata specimens. 


\section{Paralia guyana MacGillivary (Table 1, Fig. 3)}

Description of specimen morphology based on LM. Straight chains were formed of interlocking cells (Fig. 3A \& B). Sibling valve chains linked with well-developed interlocking. Cell chains were mostly $<20$ cells. Frustules were cylindrical and heavily silicified, 6.7-22.0 $\mu \mathrm{m}$ in diameter and 9.0-26.9 $\mu \mathrm{m}$ in pervalvar axis. Valves robust, circular (Fig. 3F). Internal valves had lined up along the central region of internal spines (Fig. 3F, thin arrow) and marginal pore (Fig. 3F, thick arrow).

Description of specimen morphology based on SEM. Straight chains were formed of interlocking cells (Fig. 3C $\&$ D). Two types of valves were observed, separation (Fig. 3E) and intercalary (Fig. 3G), each with two forms: relief (long, capitate marginal spines) (Fig. 3H, thin arrow) and intaglio (short, blunt marginal spines, Fig. $3 \mathrm{H}$, thick arrow). Marginal linking spines occurred only along the face margin of intercalary valves and fit into notches (Fig. $3 \mathrm{H})$ between the marginal, short, blunt, square-shouldered spines of a sibling valve. Internal linking spines were of varied size, 2.0-16.9 in $10 \mu \mathrm{m}$, tapered in height towards the central valve area (Fig. 3D, E \& G). The marginal and internal linking spines of sibling valves interlocked to maintain cells in colonies (4.3-10.0 in $10 \mu \mathrm{m})$ (Fig. 3H). Commonly, only one ring of regular, mediumor small-sized pores was present on valves (Fig. 3E \& G, thick arrow). Separation valve faces were free of marginal spines, but may have had prickles (Fig. 3D, thin arrow). Separation valves had convex valve faces (Fig. 3D) and were lined up along the central region of internal spines (Fig. 3E, thin arrow) connecting sibling separation valves (Fig. 3D, thick arrow). Valves ware perforated by small or large, poroid areolae in a cross pattern (Fig. 3G), 4.2-4.9 in $1 \mu \mathrm{m}$ in internal valve view. The fenestrae were clearly at the base of the valve face and the mantle part; 4.4-13.8 in $10 \mu \mathrm{m}$ in girdle view. Closer to the valve face, above each fenestra, was a large circular pore (Fig. $3 \mathrm{H}$, dashed square), which corresponded to the presence of a marginal linking spine in intercalary valves. Thus, fenestrae and marginal linking spines occurred in an almost $1: 1$ ratio. (Fig. 3H). The cingula were composed of a number of copulae with regularly spaced, centrally located slits (Fig. $3 \mathrm{D}$, arrowhead). The mantle rim was smooth in internal valve view (Fig. 3I). Small, slit rimoportulae were located just below the overhanging edge of the mantle, and each rimoportula had irregular space; 1.3-3.4 in $10 \mu \mathrm{m}$ (Fig. 3I, arrowheads). Striae ran below the mantle edge in internal view. Striae were perpendicular to the mantle edge and were parallel to each other when they were present (37.7-
69.8 in $10 \mu \mathrm{m})$. Striae varied in length and did not extend to the valve centre.

\section{Paralia marina (W. Smith) Heiberg (Table 1, Fig. 4)}

Basionym: Orthosira marina Smith 1856

Description of specimen morphology based on LM. Cells commonly shortly cylindrical, linked to form straight chains (Fig. 4A). Cell chains were mostly $<30$ cells. Frustules were cylindrical and strongly silicified, 4.0-27.4 $\mu \mathrm{m}$ in diameter and 3.6-9.8 $\mu \mathrm{m}$ in pervalvar axis. Valves almost circular (Fig. 4D \& F). Separation valves had lined up along the central region of internal spines (Fig. 4D, thin arrow) and marginal pore (Fig. 4D, thick arrow). Internal valves had lined up along the central region of internal spines (Fig. 4F, thin arrow) and marginal pore (Fig. 4F, thick arrow).

Description of specimen morphology based on SEM. Straight chains were formed of interlocking cells (Fig. 4B \& C). Two types of valves were observed, separation (Fig. 4C \& E) and intercalary (Fig. 4G \& H), each with two forms, relief (long, capitate marginal spines) (Fig. 4B \& $\mathrm{H}$ ) and intaglio (short, blunt marginal spines) (Fig. 4B $\& \mathrm{H}$ ). Capitate marginal linking spines (Fig. $4 \mathrm{H}$, thin arrow) occurred only along the face margin of intercalary valves and fit into notches (Fig. $4 \mathrm{H}$, thick arrow) between the marginal, short, blunt, square-shouldered spines of a sibling valve. Internal linking spines of varied size, 4.012.7 in $10 \mu \mathrm{m}$, tapered in height towards the smooth central valve area (Fig. 4C, E \& G, thin arrow). The marginal and internal linking spines of sibling valves interlocked to maintain cells in colonies (Fig. 4C, thin arrow). Generally, two rings of larger and smaller pores were irregularly present at the valve face margin of intercalary valves (Fig. $4 G$, thick arrow). Separation valves did not have marginal linking spines (Fig. 4C, E \& G). Separation valves had smooth valve faces and were lined up along the central region of internal spines (Fig. 4E, thin arrow). Normally, one ring of regular, large- to medium-size pores was present on the valve face (Fig. 4E, thick arrow). Valve faces were flat and with a cylindrical girdle outline of the frustule (e.g., Fig. 4B \& C). All valves were perforated by small or large, poroid areolae in a decussate pattern (Fig. 4C, dashed square), 3.6-6.3 in $1 \mu \mathrm{m}$ in internal valve view. The fenestrae were mostly obvious at the base of the valve face and the mantle met part; 5.5-17.0 in $10 \mu \mathrm{m}$ in girdle view (Fig. $4 \mathrm{H}$, dashed square). Closer to the valve face, above each fenestra was a large circular pore (Fig. 4B \& $\mathrm{H})$, which corresponded to the presence of a marginal linking spine in intercalary valves. Thus, fenestrae and 

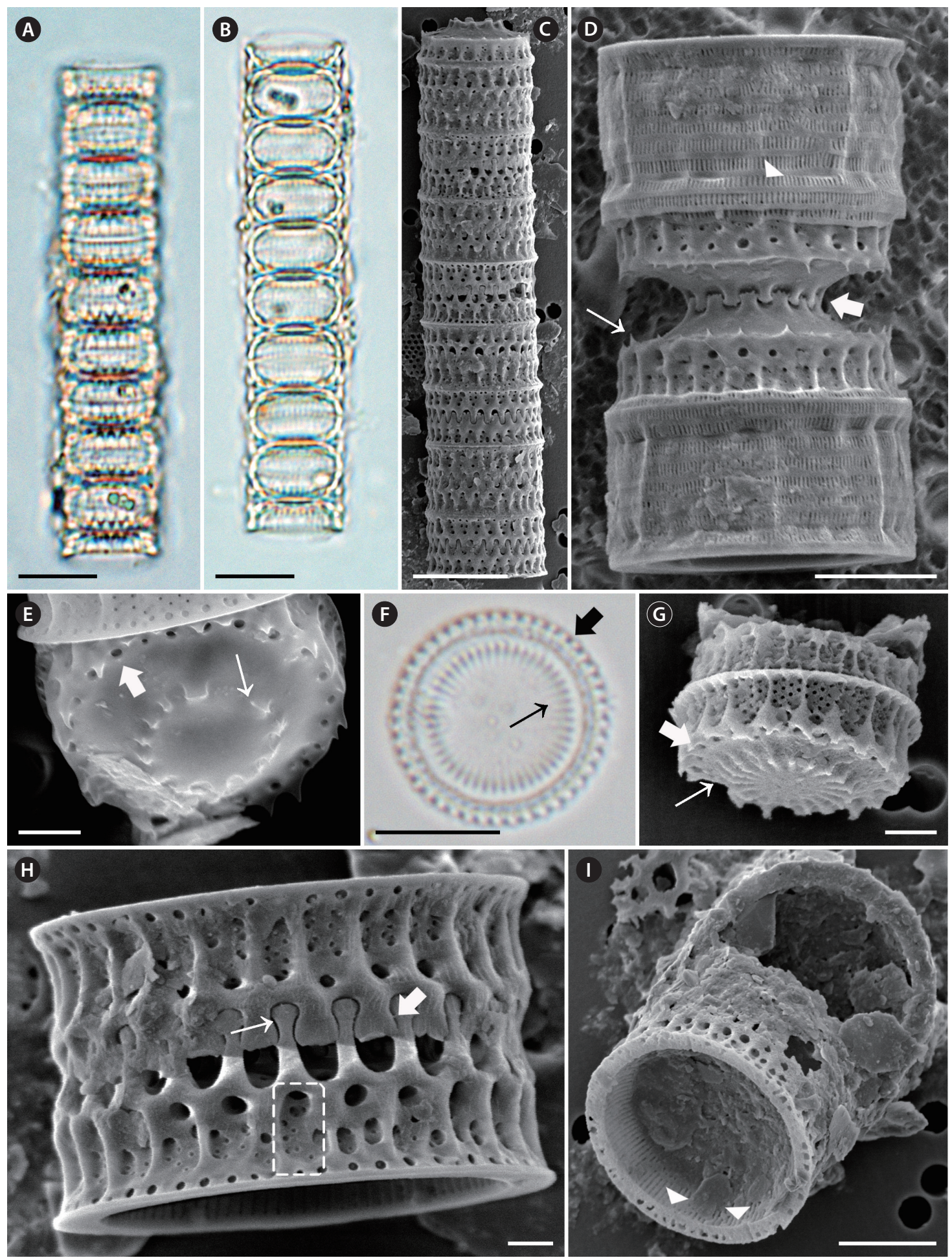

Fig. 3. Micrographs of Paralia guyana taken using light microscopy (A, B \& E) and scanning electron microscopy (C, D \& F-I). (A-C) Girdle view of eight-celled chain. Upper (A) and middle (B) focus girdle view of the specimen. (D) Girdle view of interlocked, sibling, separation valves with internal linking spines (thick arrow); slits in copulae (arrowhead) and well-developed prickles (thin arrow). (E) Valve view of separation valve. Internal linking spines (thin arrow), marginal pore (thick arrow). (F) Valve view of intercalary valve. Internal linking spines (thin arrow), marginal pore (thick arrow). (G) Valve view of intercalary valve with interlocking radiating processes and fenestrae. Internal linking spines (thin arrow), marginal pore (thick arrow). (H) Girdle view of interlocked, sibling, intercalary valves. Extended marginal linking spines (thin arrow) in relief valve; short, blunt marginal linking spines (thick arrow) in intaglio valve; visible fenestra (dashed square). (I) Internal valve view with internal striae and rimoportulae. Rimoportula (arrowheads). Scale bars represent: A-C \& E, $10 \mu \mathrm{m} ; \mathrm{D} \& \mathrm{H}, 5 \mu \mathrm{m} ; \mathrm{F} \& \mathrm{G}, 2 \mu \mathrm{m} ; \mathrm{I}, 1 \mu \mathrm{m}$. 

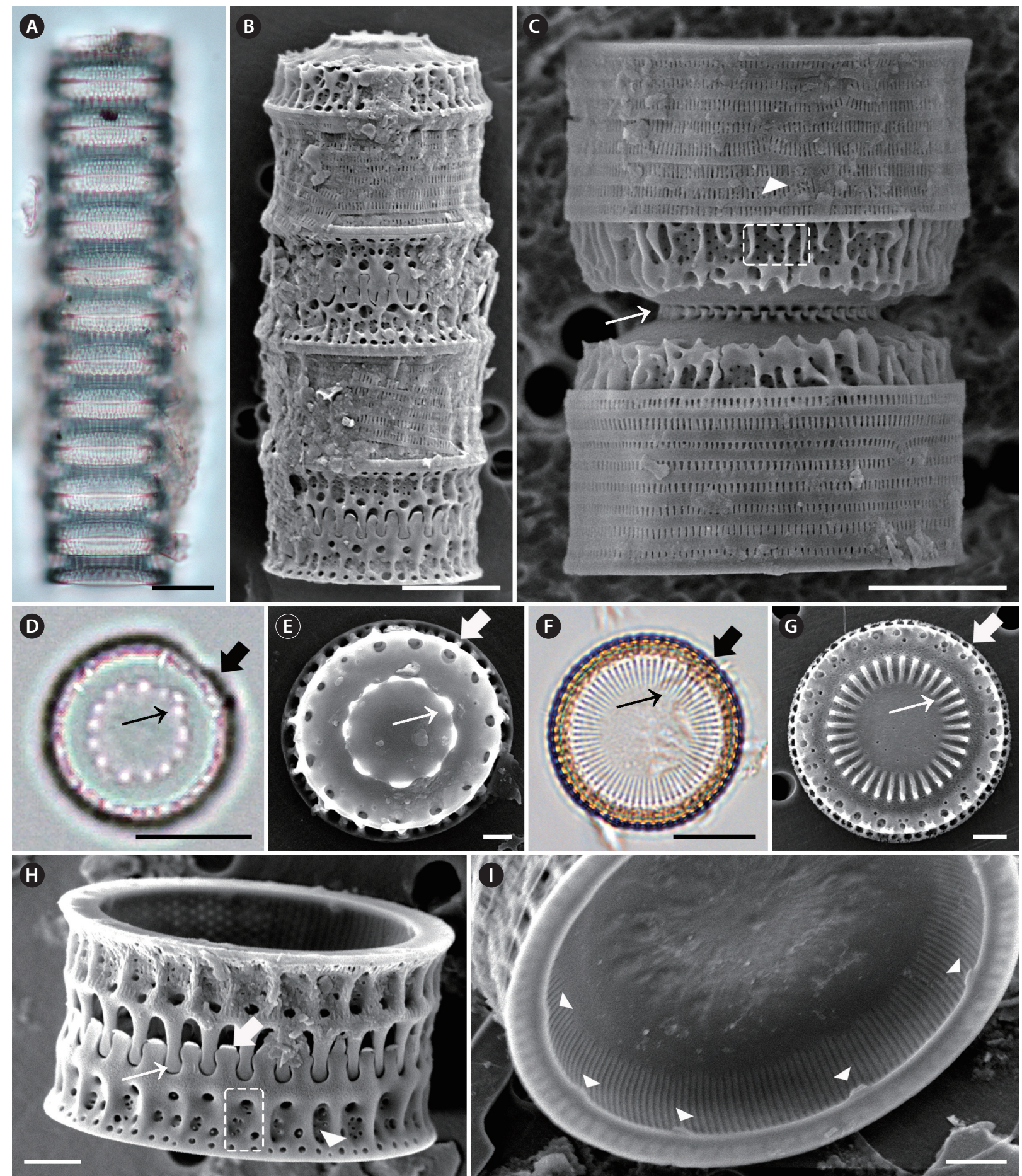

Fig. 4. Micrographs of Paralia marina taken using light microscopy (A, D \& F) and scanning electron microscopy (B, C, E \& G-I). (A \& B) Girdle view of chained cells. Upper (A) focus girdle view of 11-celled chain. (C) Girdle view of interlocked, sibling, separation valves. Slits in copulae (arrowhead) and internal linking spines (thin arrow), decussated pattern of poroid areolae (dashed square). (D) Valve view of separation valve. Internal linking spines (thin arrow); marginal pore (thick arrow). (E) Valve view of separation valve. Internal linking spines (thin arrow), marginal pore (thick arrow). (F) Valve view of intercalary valve. Internal linking spines (thin arrow), marginal pore (thick arrow). (G) Valve view of intercalary valve with interlocking radiating processes. Internal linking spines (thin arrow); medium-sized marginal pore (thick arrow). (H) Sibling valves held together by long and capitate-shaped marginal linking spines. There are two rings of pores and fenestrae parallel to the mantle edge. Marginal linking spines (thin arrow) in relief valve; marginal linking spines (thick arrow) in intaglio valve; rimoportula (arrowhead); external pore of the rimoportula (dashed square). (I) Internal valve view with internal striae and rimoportulae. Rimoportula (arrowheads). Scale bars represent: A \& F, $10 \mu \mathrm{m} ; \mathrm{B}-\mathrm{D}, 5$ $\mu \mathrm{m} ; \mathrm{E}, 1 \mu \mathrm{m} ; \mathrm{G}-\mathrm{I}, 2 \mu \mathrm{m}$. 
marginal linking spines occurred in a $1: 1$ ratio (Fig. 4B \& $\mathrm{H})$. Cingula were composed of a number of copulae, and each copula carried regularly spaced, centrally located slits (Fig. 4C, arrowhead). The mantle rim was smooth in internal valve view (Fig. 4I). Small, slit rimoportulae were located just below the mantle overhanging edge, and each rimoportula had irregular space; 1.3-3.1 in $10 \mu \mathrm{m}$ (Fig. 4I, arrowheads). Minute external openings of the rimoportulae were observed in many valves (Fig. $4 \mathrm{H}$, arrowhead). Striae began slightly below the mantle edge in internal view. Striae were perpendicular to the mantle edge and were parallel to each other when they were present (34.1$63.7 \mathrm{in} 10 \mu \mathrm{m})$. Striae varied in length and did not extend to the valve centre.

\section{Paralia cf. obscura MacGillivary (Table 1, Fig. 5)}

Description of specimen morphology based on LM. Straight chains were formed of interlocking cells (Fig. 5A). Cell chains were mostly $<20$ cells. Frustules were cylindrical and circular, strongly silicified, 11.1-28.7 $\mu \mathrm{m}$ in diameter and 4.4-13.5 $\mu \mathrm{m}$ in pervalvar axis. Valves almost circular (Fig. 5C \& D). Separation valves had lined up along the central region of internal spines (Fig. 5C, thin arrow) and marginal pore (Fig. 5C, thick arrow). Internal valves had lined up along the central region of internal spines (Fig. 5D, thin arrow) and marginal pore (Fig. 5D, thick arrow).

Description of specimen morphology based on SEM. Straight chains were formed of interlocking cells (Fig. 5B). Two types of valves were observed, separation (Fig. 5C) and intercalary (Fig. 5D \& E). Separation and intercalary valves were also observed in this obscured fenestra morphotype; intaglio and relief valves were observed in intercalary valves; relief (rounded tips of spatulate spines) (Fig. 5G, thin arrow) and intaglio (short, flat tips of marginal spines) (Fig. 5F \& G, thick arrow). Separation valves were not found, Marginal linking spines, 3.8-11.2 in 10 $\mu \mathrm{m}$, were present on intercalary valves (Fig. 5G, thin arrow). Internal linking spines varied in size, 6.3-12.0 in 10 $\mu \mathrm{m}$, tapered in height towards the smooth valve central area (Fig. 5E \& F, thin arrow). The marginal and internal linking spines of sibling valves interlocked to maintain cells in colonies (Fig. 5B \& G). The exterior ring of pores on the valve face contained large (outside) and small (inside) pores (Fig. 5E, thick arrow). In most specimens, each pore in the exterior ring was bordered on each side by a marginal linking spine (Fig. 5E, thick arrow \& F, arrowhead). The arrangement of the interior ring of pores was variable (Fig. 5E, thick arrow). In some valves, pores were irregularly spaced (Fig. 5E). The fenestrae were obscure at the base of the valve face and the mantle met part; 2.5-11.0 in $10 \mu \mathrm{m}$ in girdle view (Fig. 5F, dashed square). Mantle fenestrae were incompletely silicified valves when observed in SEM. A siliceous cover normally obscured fenestrae and each section of this siliceous cover. Each fenestra was a large circular pore (Fig. 5B, F \& G), which corresponded to the presence of a marginal linking spine in intercalary valves. The fenestrae and marginal linking spines mostly occurred in a ratio of $2: 1$ (Fig. 5G), but sometimes occurred in a ratio of $1: 1$ (Fig. 5B). Cingula were composed of a number of copulae and were plain except for regularly spaced slits (Fig. 5G, arrowhead). Internally, the mantle edge was flat and smooth. Small, simple slit rimoportulae were located just below the mantle edge and each rimoportula had irregular space; 2.7-3.7 in $10 \mu \mathrm{m}$ (Fig. 5G, black arrowhead). Striae began slightly below the mantle edge in internal view. Striae were perpendicular to the mantle edge and were parallel to each other when they were present (46.6 in $10 \mu \mathrm{m})$. Striae varied in length and did not extend to the valve centre.

Remark. MacGillivary and Kaczmarska (2013) recently recorded $P$. obscura. According to MacGillivary and Kaczmarska (2013), this species exists in the fossil record. In this study, this species was only found net sample. We could not be sure that this specimen was a fossil species. Thus, we designated it as $P$. cf. obscura. Moreover, the range of biometric data of the $P$. cf. obscura that we observed during this study in Korean coastal waters was wider than that of the previously studied P. obscura.

\section{Paralia sulcata (Ehrenberg) Cleve (Table 1, Fig. 6)}

\author{
Basionym. Gaillonella sulcata Ehrenberg 1838 \\ Synonym. Gaillonella sulcata Ehrenberg 1838 \\ Melosira sulcata (Ehrenberg) Kützing 1844 \\ Paralia sulcata var. genuina Grunow 1884 \\ Orthosira marina Smith 1856 \\ Melosira marina (Smith) Janisch 1862 \\ Paralia marina (Smith) Heiberg 1863
}

Description of specimen morphology based on LM. Cells cylindrical, united in filamentous colonies (Fig. 6A \& B). Sibling valve chains linked with well-developed interlocking (Fig. 6A). Chains could reach $>50$ cells, but were mostly $<20$ cells. Frustules were circular, cylindrical, and strongly silicified, 8.4-50.6 $\mu \mathrm{m}$ in diameter and 3.8$17.8 \mu \mathrm{m}$ in pervalvar axis. Separation valves had lined up along the central region of internal spines (Fig. 6E, thin arrow). Internal valves had lined up along the central region of internal spines (Fig. 6G, thin arrow) and marginal pore (Fig. 6G, thick arrow). 

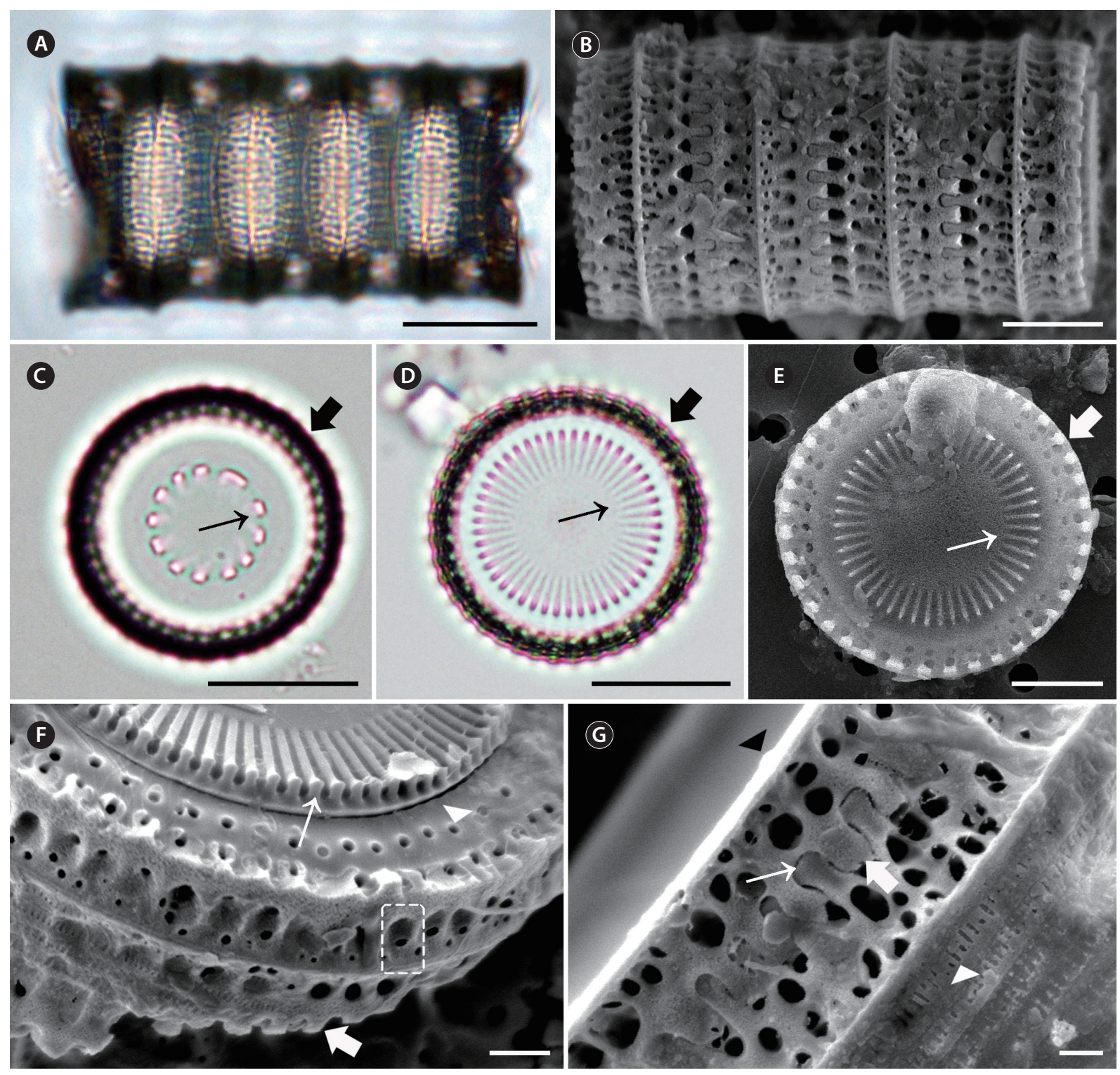

Fig. 5. Micrographs of Paralia cf. obscura taken using light microscopy (A, C \& D) and scanning electron microscopy (B \& E-G). (A \& B) Girdle view of four-celled chain. Upper (A) focus girdle view of the specimens. (C) Valve view of separation valve. Irregular pattern of internal linking spines (thin arrow); marginal pore (thick arrow). (D) Valve view of intercalary valve. Internal linking spines (thin arrow), marginal pore (thick arrow). (E) Valve view of intercalary valve with interlocking radiating processes. Internal linking spines (thin arrow), medium-sized marginal pore (thick arrow). (F) Valve view of intercalary valve. Internal linking spines (thin arrow), marginal pore (arrowhead), broken marginal linking spine (thick arrow), visible narrow fenestrae (dashed square). (G) Girdle view of two sibling valves showing the irregular spatulate shape of marginal linking spines and copulae. Marginal linking spines (thin arrow) in relief valve, marginal linking spines (thick arrow) in intaglio valve, slits in copulae (arrowhead). Scale bars represent: $A, C \& D, 10 \mu \mathrm{m} ; B$ \& $E, 5 \mu \mathrm{m} ; \mathrm{F}, 2 \mu \mathrm{m} ; \mathrm{G}, 1 \mu \mathrm{m}$.

Description of specimen morphology based on SEM. Cells cylindrical, united in filamentous colonies (Fig. 6C). Two types of valves, intercalary and separation, were found. Intercalary valves were observed in intaglio and relief forms (sensu Crawford 1979). Separation valves were also found in intaglio forms and relief forms, but the two forms of valves were nearly identical. Internal linking spines of varied size, 3.8-23.2 in $10 \mu \mathrm{m}$, tapered in height towards the valve centre and were almost flat (Fig. 6F, thin arrow). The marginal and internal linking spines of sibling valves interlocked to form colonies (Fig. 6C \& D). Intercalary valves had slender, spatulate marginal linking spines with round tips (Fig. 6I, thin and thick arrow): 2.1-13.4 in $10 \mu \mathrm{m}$. The tips of the spines were sometimes broken off in specimens. Generally, two rings of pores were found at the marginal area of the valve face; the external ring was 

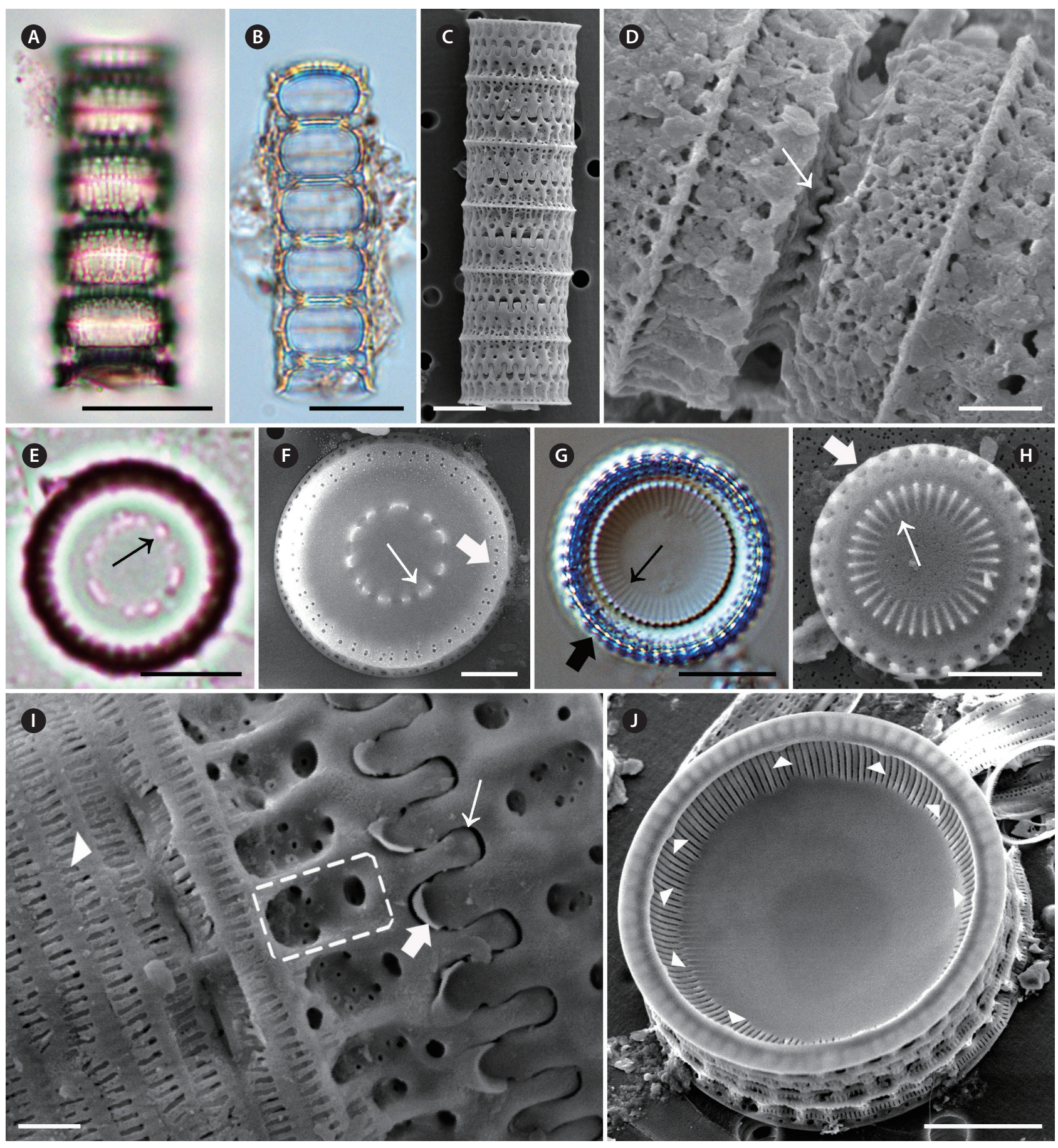

Fig. 6. Micrographs of Paralia sulcata taken using light microscopy (A, B, E \& G) and scanning electron microscopy (C, D, F \& H-J). (A-C) Girdle view of chained cells. Upper (A) and middle (B) focus girdle view of the specimen. (D) Girdle view of interlocked, sibling, separation valves. Wedgeshaped internal linking spines (thin arrow). (E) Valve view of separation valve. Irregular pattern of internal linking spines (thin arrow). (F) Valve view of separation valve. Irregular pattern of internal linking spines (thin arrow), marginal pore (thick arrow). (G) Valve view of intercalary valve. Internal linking spines (thin arrow), marginal pore (thick arrow). (H) Valve view of intercalary valve with interlocking radiating processes. Internal linking spines (thin arrow), marginal pore (thick arrow). (I) Girdle view of intercalary valve. Slender, spatula, rounded tips of internal linking spines (thin arrow) in relief valve; flat tip of marginal linking spines (thick arrow) in intaglio valve; obscure fenestrae (dashed square); slits in copulae (arrowhead). (J) Internal valve view with internal striae and rimoportulae. Rimoportula (arrowheads). Scale bars represent: A, B, E \& G, $10 \mu \mathrm{m} ; \mathrm{C}, \mathrm{F}$, $H \& J, 5 \mu \mathrm{m} ; \mathrm{D}, 2 \mu \mathrm{m} ; \mathrm{I}, 1 \mu \mathrm{m}$. 
made of larger pores, while the inner ring was made of small pores. The inner ring pores were sometimes irregular (Fig. 6F \& H, thick arrow). Separation valves lacked external linking spines at the edge of the valve face and had less pronounced knob-like internal linking spines toward the central area (Fig. 6F, thin arrow). The junction of the valve face (Fig. 6D, thin arrow) and mantle produced a square shape in both the intercalary and separation valves. The basal silica layer was composed of coarse pores arranged in striae. Each stria consisted of pores which stretched parallel to the pervalvar axis and formed a decussate pattern, 2.6-6.2 in $1 \mu \mathrm{m}$ in internal valve view. The U-shaped fenestrae were mostly obvious at the base of the valve face and the mantle met part; 4.0-19.1 in 10 $\mu \mathrm{m}$ in girdle view (Fig. 6I, dashed square). Above each fenestra was a large circular pore in the valve face (Fig. 6I, dashed square), and a marginal spine was located the apex of each fenestra (Fig. 6I). Thus, fenestrae and marginal linking spines mostly occurred in a $1: 1$ ratio (Fig. 6C \& I). Cingula were composed of a number of copulae, and each copula had regularly spaced, centrally located slits (Fig. 6I, arrowhead). The mantle rim was smooth in internal valve view (Fig. 6J). Small, lip-like rimoportulae were located on the projection of the mantle edge and were irregularly spaced; 2.1-5.9 in $10 \mu \mathrm{m}$ (Fig. 6J). Striae began slightly below and ran perpendicular to the projection of the mantle edge and were parallel to each other (Fig. 6J); 28.3-64.7 in $10 \mu \mathrm{m}$. Within each stria, regularly spaced areolae particularly appeared in valves (Fig. 6J).

\section{DISCUSSION}

\section{Comparison of Paralia morphology}

We found that the following characteristics are important for separating the genus Paralia: 1) features of the valve face on the separation valve; 2 ) the shape of the linking spines; 3 ) the number of linking spines in the separation and intercalary valves; 4 ) the shape of fenestrae; and 5) the number of fenestrae in the girdle view (Figs 2-6). Distinctive features of the Paralia species in this study were the morphology of the frustular structure, including the prickles on the separation valve face, the number of fenestrae, and the linking spines, which were present in all Paralia species in this investigation.

Paralia guyana was reported as a new species from Shediac Valley, Canada (MacGillivary and Kaczmarska 2015). MacGillivary and Kaczmarska (2015) referred to four genodemes of the species: P. guyana 'smooth' valves,
P. guyana 'caisn' valves, P. guyana 'capebreton' valves, and $P$. guyana 'servidei' valves. These taxa are all morphologically similar species, but are different in the morphology of the separation valves. In addition, these taxa are mostly reliably delineated based on DNA sequence analyses (MacGillivary and Kaczmarska 2015). The species observed in this study has P. guyana 'caisn' valves. This species is distinguished from other species by prickles on the separation valve face. In comparing $P$. guyana and $P$. longissima sensu lato (e.g., $P$. longissima, $P$. allisonii, $P$. crawfordii, and $P$. ehrmanii), both taxa have a distinctive separation valve face; $P$. guyana has short and variably shaped prickles, but these could not be observed in LM. Furthermore, P. longissima sensu lato has long, tapering marginal spines on the separation valves, a distinctive characteristic of this species.

Paralia fenestrata is distinguished from the other Paralia species by having square-shoulder-shaped separation valves and fenestrae on the mantle of the valves. Additionally, the internal and external openings of the rimoportulae in the two species are small, simple slits, or clear pores. Furthermore, the surface relief of the abvalvar mantle rim is scallop shaped in P. sulcata, but smooth in P. fenestrata. This study reached the same conclusions as those of Sawai et al. (2005). However, the morphology of the advalvar mantle rim is similar in $P$. sulcata and $P$. fenestrata.

Paralia marina was not easy to distinguish from $P$. cf. obscura and P. sulcata in Korean coastal waters, because the morphological characters of this species are highly variable. Furthermore, clear molecular genetic data is not yet available. Therefore, their relationship to P. marina cannot be determined (MacGillivary and Kaczmarska 2015). The shape and density of the fenestrae of P. marina differs from those of $P$. fenestrata and P. sulcata; the latter two species have U-shaped fenestrae which are not covered by completely silicified valves.

Paralia cf. obscura differs from other species by its ratio of occurrence of marginal linking spines and fenestrae. This ratio can be either $1: 1$ or 2: 1 (MacGillivary and Kaczmarska 2013). Crawford (1979) showed that $P$. sulcata has two fenestrae per marginal linking spine. However, MacGillivary and Kaczmarska (2013) explained that P. sulcata specimens from Ehrenberg's material always had one fenestra corresponding to one marginal linking spine. $P$. cf. obscura has two fenestrae corresponding to one marginal linking spine. Furthermore, MacGillivary and Kaczmarska (2012) observed a 2: 1 ratio of fenestrae to marginal linking spines for P. allisonii, P. crawfordii, and P. ehrmanii. According to Sawai et al. (2005), P. fenestrata has a 


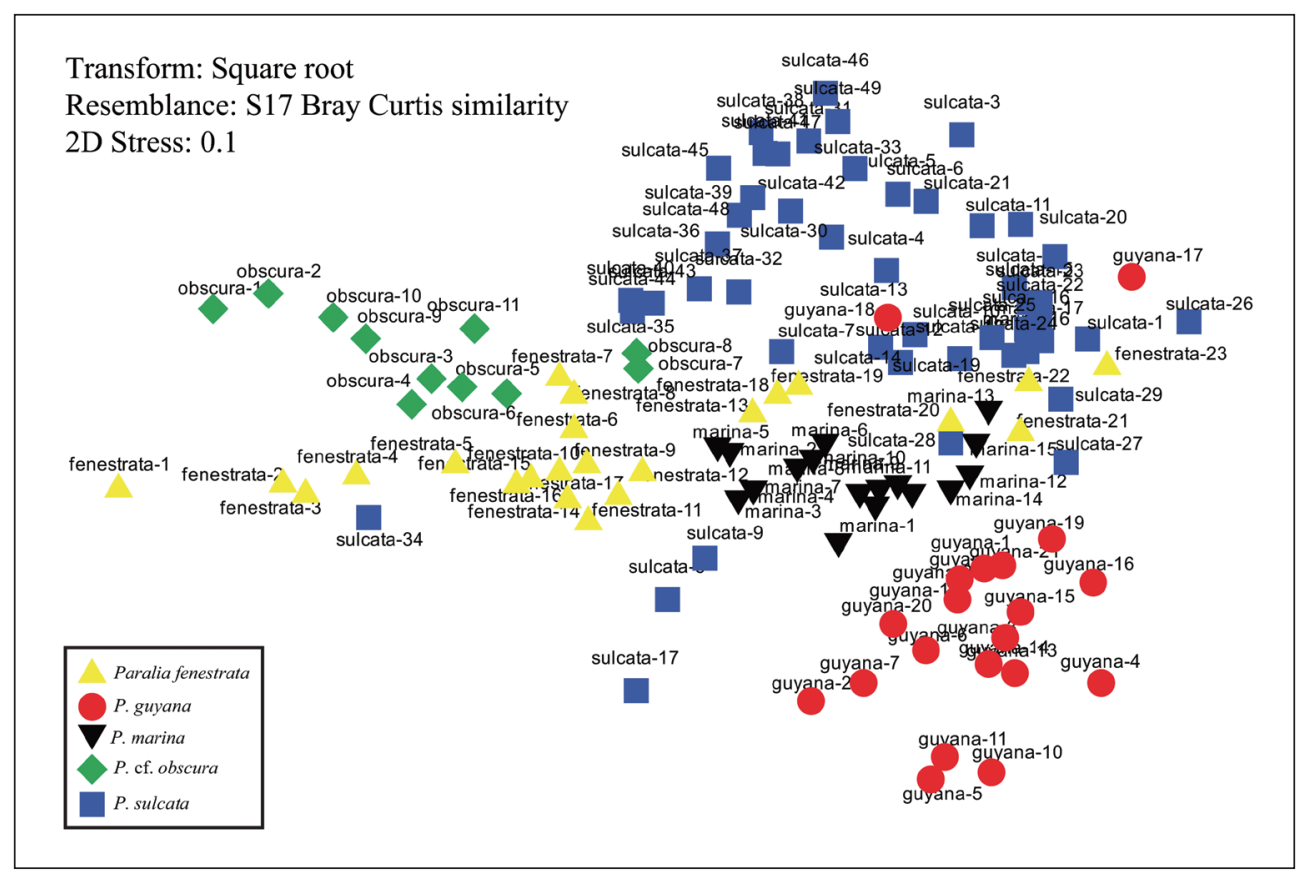

Fig. 7. Non-metric multidimensional scaling analysis plot based on Bray Curtis similarities between Paralia species in this study and 5 species distinguished by CLUSTER analysis (symbols). Yellow symbols represent species in Paralia fenestrata, red symbols represent species in P. guyana, black symbols represent species in P. marina, green symbols represent species in $P$. cf. obscura, and blue symbols represent species in $P$. sulcata.

$1: 1$ ratio of fenestrae to marginal linking spines, despite a large variation in valve diameter. $P$. cf. obscura also has a 2: 1 ratio of fenestrae to marginal linking spines in Korean coastal waters. Thus, the fenestra to marginal linking spine ratio of $P$. cf. obscura is a diameter-independent morphometric characteristic that supports our result.

Most morphological differences of the genus Paralia can only be resolved under SEM. Thus, species of the genus Paralia in Korean coastal waters may be considered morphologically similar species.

\section{Comparison of morphometric criteria for identi- fication}

Although we tried to confirm the morphological differences among species, most quantitative and qualita- tive characteristics of the five species were similar and overlapping in ranges of length (Table 1). It is difficult to verify a clear difference between previously studied data (Sims and Crawford 2002, Sawai et al. 2005, Konno and Jordan 2008) and this study. Thus, distinguishing characteristics must be modified for precise identification of Paralia species. As we mentioned in the introduction, the Paralia species should be examined under an electron microscope to determine the cell ultrastructure. In addition, rimoportulae and striae morphology were not useful in the analysis of Paralia species from the Korean coastal waters. Other ultrastructures (e.g., marginal linking spines, internal linking spines, and fenestrae in the girdle view) were more useful for identification using morphological analysis. This study used the pervalvar axis, internal linking spines, marginal linking spines, and

Table 2. Comparison of ratio of Paralia species from Korean coastal waters

\begin{tabular}{lccccc}
\hline \multicolumn{1}{c}{ Characters } & P.fenestrata & P.guyana & P. marina & P.cf. obscura & P.sulcata \\
\hline Pervalvar axis $(\mu \mathrm{m})$ / Diameter $(\mu \mathrm{m})$ & $0.49 \pm 0.12$ & $0.48 \pm 0.13$ & $0.46 \pm 0.10$ & $0.40 \pm 0.10$ & $0.45 \pm 0.13$ \\
Internal linking spines / Diameter $(\mu \mathrm{m})$ & $0.64 \pm 0.37$ & $0.58 \pm 0.25$ & $\mathbf{0 . 8 0} \pm \mathbf{0 . 3 1}$ & $0.53 \pm 0.21$ & $\mathbf{1 . 1 7} \pm \mathbf{0 . 4 7}$ \\
Marginal linking spines / Diameter $(\mu \mathrm{m})$ & $0.60 \pm 0.29$ & $0.76 \pm 0.23$ & $\mathbf{0 . 8 3} \pm \mathbf{0 . 4 5}$ & $\mathbf{0 . 4 6} \pm \mathbf{0 . 1 3}$ & $0.63 \pm 0.18$ \\
Fenestrae / Diameter $(\mu \mathrm{m})$ & $0.50 \pm 0.20$ & $\mathbf{0 . 7 3} \pm \mathbf{0 . 1 9}$ & $0.68 \pm 0.52$ & $\mathbf{0 . 4 0} \pm \mathbf{0 . 1 2}$ & $0.59 \pm 0.27$ \\
\hline
\end{tabular}

Values are presented as average \pm standard deviation.

Bold values show diagnostic characters. 
fenestrae to diameter ratio to compare the characteristics of Paralia species from the Korean coastal waters. The average values shown in Table 2 confirm the results, and Fig. 7 confirmed the identification of Paralia species by a combination of the newly selected characteristics. The ratio of the pervalvar axis to diameter was not very useful in differentiating species, but the ratio of internal linking spines to diameter, the ratio of marginal linking spines to diameter, and the ratio of fenestrae to diameter was useful. In the case of P. sulcata and P. marina, the relatively high values of $1.17 \pm 0.47$ and $0.80 \pm 0.31$, respectively, were unlike other species. Paralia marina had the highest ratio of marginal linking spines per diameter $(0.83 \pm 0.45)$. Concurrently, $P$. cf. obscura had a value of $0.46 \pm 0.13$, the minimum value, highlighting the differences among the five species compared. Paralia guyana had the highest ratio of fenestrae to diameter $(0.73 \pm 0.19)$, while $P$. cf. $o b$ scura had the lowest value $(0.40 \pm 0.12)$. From the MDS ordination technique (Fig. 7), we determined the degree of morphological difference among the species. The species separated by the MDS are evident in the ordination analysis, with a stress value of 0.01 , indicating that the graphical distances among the species were close to the original similarities. Four species, except for $P$. fenestrata, were easily distinguished by the new approach to morphometric analysis. Distribution patterns of $P$. fenestrata in the MDS analysis was widely distributed from $P$. cf. obscura to $P$. marina. These results indicated that for the identification of $P$. fenestrata, it is better to use conventional characteristics as opposed to the newly proposed criteria. Consequently, when combining four morphological characteristics, P. marina was classified as having high values for two characteristics (ratio of internal linking spines and marginal linking spines to diameter), which differentiated it from other species of the Korean coastal waters. These results are shown in Fig. 7 and can be confirmed in the distribution patterns. Paralia cf. $o b$ scura was separated due to a low value for two characteristics (ratio of marginal linking spines and fenestrae to diameter), which differentiated it from other species. Thus, analyses based on the combination of morphological and morphometric data are useful for the identification of Paralia species.

\section{ACKNOWLEDGEMENTS}

This research was supported by the National Institute of Biological Resources (NIBR No. 201501204) and the Ministry of Environment of the Republic of Korea (\#416-
111-008, Development of biosensor technology using microalgal resources of The Eco-Innovation Project in 2015). And, we thank Dr. Seung Won Jung of the South Sea Research Institute, Korea Institute of Ocean Science \& Technology, South Korea, for commenting on the manuscript.

\section{SUPPIEMENTARY MATERIAL}

Supplementary Table S1. Collection site information of the Paralia specimens examined in the present study (www.e-algae.kr).

\section{REFERENCES}

Clarke, K. R. 1993. Non-parametric multivariate analyses of changes in community structure. Aust. J. Ecol. 18:117143.

Clarke, K. R. \& Ainsworth, M. 1993. A method of linking multivariate community structure to environmental variables. Mar. Ecol. Prog. Ser. 92:205-219.

Clarke, K. R. \& Warwick, R. M. 2001. Changes in marine communities: an approach to statistical analysis and interpretation. 2nd ed. Primer-E, Plymouth, 172 pp.

Cleve, P. T. 1873. On diatoms from the Arctic Sea. Bihang till Kongliga Svenska Vetenskaps-Akademiens Handlingar 1:1-28.

Crawford, R. M. 1979. Taxonomy and frustular structure of the marine centric diatom Paralia sulcata. J. Phycol. 15:200-210.

Crawford, R. M., Sims, P. A. \& Hajós, M. 1990. The morphology and taxonomy of the centric diatom genus Paralia. I. Paralia siberica comb. nov. Diatom Res. 5:241-252.

Droop, S. J. M. 1994. Morphological variation in Diploneis smithii and D. fusca (Bacillariophyceae). Arch. Protistenkd. 144:249-270.

Droop, S. J. M., Mann, D. G. \& Lokhorst, G. M. 2000. Spatial and temporal stability of demes in Diploneis smithii/D. fusca (Bacillariophyta) supports a narrow species concept. Phycologia 39:527-546.

Ehrenberg, C. G. 1838. Die Infusionshierchen als vollkommene Organismen: Ein Blick in das tiefere organische Leben der Natur. Leopold Voss, Leipzig, 548 pp.

Field, J. G., Clarke, K. R. \& Warwick, R. M. 1982. A practical strategy for analysing multispecies distribution patterns. Mar. Ecol. Prog. Ser. 8:37-52.

Garcia, M., Talgatti, D., Souza-Mosimann, R. \& Laudares-Silva, R. 2012. Morphology and distribution of Paralia Heiberg (Coscinodiscophyceae) in southern Brazil. Iherin- 
gia Sér. Bot. 67:225-235.

Goldman, N., Paddock, T. B. B. \& Shak, K. M. 1990. Quantitative analysis of shape variation in populations of Surirella fastuosa. Diatom Res. 5:25-42.

Grunow, A. 1884. Die Diatomeen von Franz Josefs-Land. Denkschriften der Kaiserlichen Akademie der Wissenschaften 48:53-112.

Guiry, M. D. \& Guiry, G. M. 2016. AlgaeBase. World-wide electronic publication, National University of Ireland, Galway. Available from: http://www.algaebase.org. Accessed Mar 9, 2016.

Hajós, S. M. 1973. Faciological and stratigraphic importance of the Miocene diatoms in Hungary. Nova Hedwig. Beih. 45:365-376

Hasle, G. R. \& Fryxell, G. A. 1970. Diatoms: cleaning and mounting for light and electron microscopy. Trans. Am. Microsc. Soc. 89:469-474.

Heiberg, P. A. C. 1863. Conspectus criticus diatomacearum danicarum. Wilhelm Priors Forlag, Copenhagen, 135 pp.

Janisch, C. 1862. Zur charakteristik des Guano's von verschieden Fundorten. Abh. Schles. Ges. Vaterl. Cult. Abth. Naturwiss. 2:1-29.

Konno, S. \& Jordan, R. W. 2008. Paralia longispina sp. nov., an extant species from Palau and Haha-jima, western North Pacific. In Likhoshway, Y. (Ed.) Proc. 19th Int. Diatom Symp., Biopress Ltd., Bristol, pp. 55-69.

Kützing, F. T. 1844. Die Kieselschaligen. Bacillarien oder Diatomeen. Nordhausen, $152 \mathrm{pp}$.

Loseva, E. I. 1988. The valve ultrastructure of fossil Paralia sulcata (Bacillariophyceae). In Simola, H. (Ed.) Proc. 10th Int. Diatom Symp., Koeltz, Koenigstein, pp. 83-91.

MacGillivary, M. L. \& Kaczmarska, I. 2012. Genetic differentiation within the Paralia longispina (Bacillariophyta) species complex. Botany 90:205-222.

MacGillivary, M. L. \& Kaczmarska, I. 2013. Lectotypification of Paralia sulcata and description of P. obscura sp. nov. (Bacillariophyta) from the Ehrenberg Collection. Diatom Res. 28:221-235.

MacGillivary, M. L. \& Kaczmarska, I. 2015. Paralia (Bacillariophyta) stowaways in ship ballast: implications for biogeography and diversity of the genus. J. Biol. Res. Thessalon. 22:2.

McQuoid, M. R. \& Nordberg, K. 2003. The diatom Paralia sulcata as an environmental indicator species in coastal sediments. Estuar. Coast. Shelf. Sci. 56:339-354.

Mou, D. \& Stoermer, E. F. 1992. Separating Tabellaria (Bacillariophyceae) shape groups based on Fourier descriptors. J. Phycol. 28:386-395.

Pappas, J. L., Fowler, G. W. \& Stoermer, E. F. 2001. Calculating shape descriptors from Fourier analysis: shape analysis of Asterionella (Heterokontophyta, Bacillariophyceae). Phycologia 40:440-456.

Pappas, J. L. \& Stoermer, E. F. 2003. Legendre shape descriptors and shape group determination of specimens in the Cymbella cistula species complex. Phycologia 42:90-97.

Řeháková, Z. 1975. Marine diatoms in Helvetian sediments of the central Paratethys. Nova Hedwig. Beih. 53:293-308.

Rhode, K. M., Pappas, J. L. \& Stormer, E. F. 2001. Quantitative analysis of shape variation in type and modern populations of Meridion (Bacillariophyceae). J. Phycol. 37:175183.

Round, F. E., Crawford, R. M. \& Mann, D. G. 1990. The diatoms: biology and morphology of the genera. Cambridge University Press, London, 747 pp.

Sawai, Y., Nagumo, T. \& Toyoda, K. 2005. Three extant species of Paralia (Bacillariophyceae) along the coast of Japan. Phycologia 44:517-529.

Schmidt, A. 1874-1959. Atlas der Diatomaceen-Kunde. O. R. Reisland, Leipzig, 1976 pp.

Schneider, C. A., Rasband, W. S. \& Eliceiri, K. W. 2012. NIH Image to Image J: 25 years of image analysis. Nat. Methods 9:671-675.

Simonsen, R. 1974. The diatom plankton of the Indian Ocean Expedition of R/V “Meteor" 1964-1965. "Meteor" Forsch. Ergeb. 19:1-107.

Sims, P. A. \& Crawford, R. M. 2002. The morphology and taxonomy of the marine centric diatom genus Paralia. II. Paralia crenulata, P. fausta and the new species, $P$. hendeyi. Diatom Res. 17:363-382.

Smith, W. 1856. A synopsixs of the British Diatomaceae. II. John van Voorst, London, 104 pp.

Stabell, B. 1996. Paralia thybergii sp. nov.: another fossil Paralia. Diatom Res. 11:155-163.

Steinman, A. D. \& Ladewski, T. B. 1987. Quantitative shape analysis of Eunotia pectinalis (Bacillariophyceae) and its application to seasonal distribution patterns. Phycologia 26:467-477.

Stoermer, E. F. \& Ladewski, T. B. 1982. Quantitative analysis of shape variation in type and modern populations of Gomphoneis herculeana. Nova Hedwig. Beih. 73:347386.

Stoermer, E. F, Qi, Y. -Z. \& Ladewski, T. B. 1986. A quantitative investigation of shape variation in Didymosphenia (Lyngbye) M. Schmidt (Bacillariophyta). Phycologia 25:494-502.

Theriot, E. \& Ladewski, T. B. 1986. Morphometric analysis of shape of specimens from the neotype of Tabellaria flocculosa (Bacillariophyceae). Am. J. Bot. 73:224-229. 